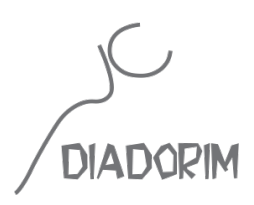

\title{
LUIZ GAMA: A IRREVERÊNCIA DA LIRA E DA MARIMBA DE UM ORFEU DA CARAPINHA NO SEGUNDO REINADO
}

\author{
LUIZ GAMA: THE IRREVERENCE OF THE LIRA AND THE \\ MARIMBA OF AN ORPHEUS OF "CARAPINHA" IN THE SECOND \\ REIGN.
}

\author{
Paulo Roberto Alves dos Santos ${ }^{1}$
}

\section{RESUMO}

Luiz Gonzaga Pinto da Gama, ou simplesmente, Luiz Gama (1830-1882), teve uma vida marcada pelos padecimentos que recaíram sobre os negros brasileiros ao longo de três séculos, com o agravante de ter nascido livre e, por volta dos dez anos de idade, ser vendido como escravo pelo próprio pai. $\mathrm{O}$ ato paterno foi revertido graças à capacidade de irresignação que o fez não só recuperar a liberdade, mas trabalhar para que centenas de outros negros a conquistassem. As ações que empreendeu no campo jurídico tiveram correspondência no âmbito da literatura por meio da publicação das Primeiras trovas burlescas de Getulino (1859), nas quais reúne poemas que esquadrinham o escravagismo do século XIX, recorrendo a uma irreverência corrosiva para mostrar as mazelas da elite do café. Depois de longo e imerecido esquecimento, Gama tornou-se objeto de interesse de pesquisadores que vêm demonstrando o valor de sua obra, cujas qualidades se evidenciam nas análises que tratam das vinculações de sua produção com a literatura afro-brasileira, por exemplo. Concomitantemente, trata-se de uma obra de relevância para o estudo da sátira em nossa literatura, uma modalidade de expressão normalmente negligenciada, embora tenha sido recorrente no período em que o poeta viveu. A partir dessa constatação, o presente trabalho tem como objetivo contextualizar a poesia satírica de Luiz Gama, considerando a maneira irreverente pela qual questiona a realidade em que vivia. Para tanto, serão empregados princípios da teoria literária em confronto com estudos dos campos da historiografia e da sociologia.

PALAVRAS-CHAVE: literatura-afro-brasileira; história da literatura; literatura e história; crítica literária.

1 PNPD-CAPES/Universidade Estadual de Santa Cruz-Ilhéus. E-mail: pauloroberto3031@uol.com.br 


\begin{abstract}
Luiz Gonzaga Pinto da Gama, or rather, Luiz Gama (1830-1882), had a life marked by the hardships which had fallen upon the black Brazilian people throughout three centuries having the worsening factor of having been born free and around ten years of age being sold by his own father. The father's doings were reversed due to Luiz's being mutinous which not only did it make him get his freedom back, but also fight for the other black people to conquer it as well. His doings regarding the legal field were related to Literature through the launching of "Primeiras trovas burlescas de Getulino" (1859), where are found poetry in which he probes slavery in the 19th century, appealing to corrosive irreverence to show the negative traits of the coffee producers elite. After a lasting and underserved oblivion, Gama became subject of interest for researchers who have been showing his compositions worth, value of which are pointed by analyses that relate his work to the afro-Brazilian literature, exemplifying. Concomitantly, it is a relevant work to study satire in Brazilian literature, a way of expression usually denied. Nonetheless, it used to be recurrent at the time in which the poet was living. For this reason, this paper has as a goal to contextualize the satirical poetry of Luiz Gama, taking in consideration the irreverent way of questioning the reality in which he was inserted. Hence, it will be used principles of theoretical literature in confrontation with historiography and sociology studies.
\end{abstract}

KEYWORDS: afro-brazilian literature, history of literature, literature and history, literary criticism.

Após uma década e meia de governos que se sucederam implementando políticas de inclusão social, de respeito às diversidades e de garantias de direitos para segmentos populacionais historicamente negligenciados pelo poder público, o Brasil ingressou em um período de retrocessos a partir de uma ruptura institucional patrocinada por setores ligados ao capital, com amparo da grande imprensa e do judiciário. O recuo aumentou com as eleições de 2018, devido à grande votação em candidatos conservadores, assegurando assentos nos legislativos estaduais e no Congresso Nacional para políticos identificados com o fundamentalismo religioso e pautas de ultradireita, que desprezam o debate intelectual, desrespeitam os direitos humanos, defendem o autoritarismo e a meritocracia, sem qualquer compaixão pelas minorias sociais. $\mathrm{O}$ viés retrógado que orientou o voto para a composição dos parlamentos, também determinou a escolha de um presidente e da maioria dos governadores que promoveram suas candidaturas atacando ações de proteção a pobres, mulheres, homossexuais, índios, negros, sem-teto, semterra, etc., pregando suas ideias a partir de um discurso de intolerância e ódio.

A posição dominante entre os eleitores significa o fim de um ciclo de conquistas de direitos iniciado em meados da década de 1970, a partir de movimentos em favor da redemocratização, que foi, ao mesmo tempo, o período mais longo de respeito à legalidade no regime republicano brasileiro e assegurado pela aplicação de princípios de uma constituição progressista. Apesar disso, os avanços alcançados passam longe da garantia de dignidade para toda a população, porque dispositivos constitucionais em benefício dos segmentos vulneráveis deixaram de ser aplicados ou o foram parcialmente, como exemplificam as carências nas áreas da saúde, da habitação, da educação, da renda e da fundiária, sem contar as deformações do aparato político e jurídico que tendem a favorecer os grupos de melhor condição econômica e ideologicamente 
mais conservadores. Assim, ao definir em quem votar, milhões de brasileiros contribuíram para criar uma situação paradoxal: valeram-se de um instrumento da democracia para conceder poderes a indivíduos propensos a ignorá-la.

Diante de tais constatações, é quase surpreendente que, nesse contexto, Luiz Gama, um homem que dedicou sua vida à defesa do direito à liberdade, tenha recebido várias honrarias pelo que realizou e pelo que representa. Talvez a principal tenha sido a sanção das Leis 13.628, que o distingue como herói nacional, inscrevendo seu nome no Livro de heróis e heroínas da pátria, e a 13.629, que o declara patrono da abolição da escravidão no Brasil, título que o coloca no panteão onde estão outras "pessoas que tiveram um papel importante e relevante em uma determinada causa" (Senado Federal, 2018). O reconhecimento oficial soma-se ao vindo de movimentos preocupados com a preservação de conquistas sociais, como demonstra a homenagem que lhe foi prestada no I Ciclo de Formação do Curso Marxismo e Pan-africanismo, promovido por organizações de cunho popular, com apoio da Universidade Federal da Bahia e da seção baiana da Ordem dos Advogados do Brasil. É importante lembrar que, em âmbito nacional, a entidade que congrega os profissionais do direito concedeu a Luiz Gama, em 2015, o título de advogado, porque "Além de ter sido um homem importante na questão do abolicionismo, foi grande jurista e advogado de teses brilhantes." (O Estado de São Paulo, 2015). Antes disso, em 2009, quando o cenário político era mais favorável a causas inclusivas,o Instituto dos Advogados do Brasil criou a medalha Luiz Gama, desenhada por Oscar Niemeyer, com a qual são agraciadas pessoas que se destacam por atos em favor da igualdade racial (IAB, 2018).

Às distinções institucionais somam-se iniciativas que reverenciam a memória de Gama, como é o caso da que Jeferson De, um cineasta paulista negro, anuncia para breve: a realização de um filme sob o título de Prisioneiro da Liberdade, no qual pretende plasmar a figura do poeta abolicionista na galeria de anti-heróis, como "Xica da Silva, Zumbi dos Palmares, Macunaíma, Zé Pequeno, Madame Satã, Ganga Zumba. Mas nenhum agindo dentro da lei." (Folha de São Paulo, 2018). Ainda no campo artístico, a biografia dramatizada Luiz Gama, uma voz pela liberdade, dirigida por Ricardo Torre, entrou em cartaz em novembro de 2017 (Geledés, 2018) e foi encenada em vários palcos do Rio de Janeiro ao longo de 2018, como atesta a programação cultural divulgada por sites especializados. Em 2013, o texto Luiz Gama ou o diabo coxo, escrito por Gabriela Rabelo, recebeu o Prêmio de Dramaturgia António José da Silva² (Embaixada de Portugal, 2018).

A dimensão do legado deixado por Luiz Gama, tanto no que diz respeito à trajetória de vida quanto no que se refere à produção literária, também pode ser avaliada pela quantidade de estudos surgidos recentemente. Apenas como ilustração, é possível citar os livros Luiz Gama: o

2 O prêmio resulta de uma parceria entre o Camões-Instituto da Cooperação e da Língua e a Fundação Nacional de Artes - Funarte. No caso de Luiz Gama ou o diabo coxo, a premiação foi anulada em seguida por desobediência ao regulamento que vetava a encenação dos textos "até a data da publicação do resultado final da seleção" (MinC, 2018). 
precursor abolicionista (2004), de José Carlos Barbosa; A luta de cada um: Luiz Gama (2005), de Myriam Fraga; Luiz Gama: o advogado dos escravos (2010), de Nelson Câmara; Luiz Gama (2010), de Luiz Carlos Santos; Luiz Gama: o libertador de escravos e sua mãe libertária, Luiza Mahin (2011), de Mozart Benedito; O advogado e o imperador: a história de um herói brasileiro (2015), de Gilberto de Abreu Sodré Carvalho. Além disso, existem artigos acadêmicos, dissertações e teses com estudos sobre sua obra literária e, nesse particular, cabe destacar a reedição crítica das Primeiras Trovas Burlescas de Luiz Gama e outros poemas (2000) e a antologia crítica Com a palavra Luiz Gama: poemas, artigos, cartas, máximas (2011), ambos sob a responsabilidade de Lígia Fonseca Ferreira ${ }^{3}$.

O interesse por Luiz Gama, seja em razão de sua luta em favor da libertação de escravos, seja por sua obra ficcional, surgiu há pouco tempo e está diretamente relacionado à ação dos movimentos negros que, a partir da década de 1970, passaram a atuar intensamente pela recuperação do passado da população de origem africana e pela valorização da sua contribuição para a formação sociocultural do Brasil. Em consequência, vem aumentando o número de pesquisadores que se dedicam à busca de indícios que possam contribuir para esclarecimentos sobre o significado real da participação de africanos e seus descendentes em acontecimentos históricos do país. Com relação a Luiz Gama, o desvendamento torna-se ainda mais relevante, porque os relatos da historiografia tradicional costumam passar a ideia de que os negros tiveram papel passivo no processo que levou à abolição da escravidão, como se não acontecessem rebeliões desde o desembarque das primeiras levas de vítimas do tráfico humano, a exemplo da que aconteceu em Porto Calvo, Alagoas, em 1575, predecessora de inúmeras outras.

Sobre esse último aspecto, a título ilustrativo e citando somente o século XIX, vale lembrar insurgências de escravos, "desde as que assolaram Salvador de 1801 a 1844, como as revoltas de Carrancas (MG, 1833), São Carlos (Campinas, 1832), Manuel Congo (Vassouras, província do Rio de Janeiro, 1838)" (SCHWARCZ; GOMES, 2018, p. 31). Na lista ainda devem ser incluídas a mais conhecida das manifestações de resistência do período, a Revolta dos Malês, que aconteceu em janeiro de 1835, também em Salvador - onde pouco antes o quilombo do Urubu abrigou negros rebelados -, como também a do Serro, em Minas Gerais, ocorrida em 1864, e a de Viana, no Maranhão, três anos mais tarde. Omitindo a relevância de tais fatos, portanto, alinhada com as correntes que sugerem a passividade dos escravizados, a historiografia literária dominante leva a crer que os negros praticamente não escreveram ou eram destituídos de pendores artísticos. A quantidade de prosadores e poetas descendentes de africanos é efetivamente pequena em relação à de brancos e, principalmente, diante das proporções da população brasileira de pele preta. Ao desconsiderar esse fator, os inventariantes que fixaram o cânone da literatura do Brasil desconsideraram a escravidão e suas sequelas perversas, não reconhecendo,

3 Em 2016, a SESI-SP Editora publicou Trovas burlescas, um dos volumes da Coleção Clássicos, que inclui obras de autores como Almeida Garrett, Eça de Queirós, Manuel Antônio de Almeida, José de Alencar e Machado de Assis.

Diadorim, Rio de Janeiro, vol. 21, n. 1, p. 160-174, jan.-jun. 2019. 
assim, que Paula Brito, Machado de Assis, José do Patrocínio, Cruz e Souza, entre outros, superaram os obstáculos da discriminação porque receberam oportunidades que foram e continuam sendo negadas a milhões de negros.

Luiz Gama teve a sua chance quase fortuitamente, segundo sua declaração na carta que escreveu a Lúcio Mendonça, documento que tem servido como referência para boa parte das informações a seu respeito:

Em 1847, contava eu 17 anos, quando para a casa do sr. Cardoso, veio morar, como hóspede, para estudar humanidades, tendo deixado a cidade de Campinas, onde morava, o menino Antônio Rodrigues do Prado Júnior, hoje doutor em direito, ex-magistrado de elevados méritos, e residente em Mogi-Guassu, onde é fazendeiro.

Fizemos amizade íntima, de irmãos diletos, e ele começou a ensinar-me as primeiras letras (GAMA, 2018).

Ainda que se possa questionar a veracidade de algumas informações da carta, particularmente em relação a alguns momentos dessa fase da vida de Gama, de acordo com Lígia Fonseca Ferreira (2018), os fatos mencionados têm verossimilhança quando comparados à biografia de dois escritores com trajetória semelhantes: Machado de Assis, veio de uma infância pobre, na qual se viu órfão e como inexistem comprovações de que tenha frequentado a escola com regularidade, tudo indica que foi entre a casa dos padrinhos ricos e o convívio com uma francesa, proprietária de uma confeitaria, (PEREIRA, 2017), que se tornou leitor e desenvolveu seu gosto literário; Lima Barreto, também mestiço, pobre e órfão de mãe era afilhado do Visconde de Ouro Preto, a cuja influência política se atribui a matrícula do futuro escritor no Colégio Pedro II.

Em uma estrutura social que praticamente impedia a mobilidade, permitindo excepcionalmente o casamento ou o diploma de curso superior como meio de ascensão para brancos que não pertencessem à classe abastada, as possibilidades de negros exercerem outra função que não a de força de trabalho beiravam à nulidade. Um exemplo da concepção do grupo dominante sobre as relações entre os segmentos populacionais é a Lei de Terras, criada em 1850, para justificar mudanças introduzidas na forma de obtenção de propriedade rural e estabelecer as diretrizes legais correspondentes. Na opinião de Boris Fausto:

A legislação foi concebida como uma forma de evitar o acesso à propriedade da terra por parte de futuros imigrantes. As terras públicas deveriam ser vendidas por um preço suficientemente elevado para afastar posseiros e imigrantes pobres (FAUSTO, 2015, p. 107).

Lilian Shwarcz (2017) afirma que a Lei de Terras foi aprovada em um momento crucial do reinado de Pedro II, porque a instabilidade política que vinha desde a década de 1830 e que motivou sucessivas rebeliões regionais havia sido superada, permitindo que o governo se voltasse para outras necessidades. As mais prementes estavam ligadas à escravidão, porque diziam 
respeito à reorganização na forma de ocupação das terras, à busca de solução para as restrições impostas pelos ingleses ao tráfico de africanos e a iniciativas de incentivo à imigração. Segundo Fausto, "os grandes fazendeiros queriam atrair imigrantes para começar a substituir a mão de obra escrava, tratando de evitar que logo eles se convertessem em proprietários" (2015, p. 108), ou seja, tratava-se de um mecanismo que aumentava a concentração de riquezas nas mãos dos latifundiários. Dar ordenamento à obtenção da posse de terras era fundamental para a sustentação política e econômica do regime, porque envolvia a produção do café, a principal riqueza para as transações comerciais internas e externas e afetava o grupo com maior força de influência nas decisões.

Assim, explica-se o porquê de uma legislação determinar que as terras públicas passassem a ser vendidas, legalizando a posse e forçando o registro de propriedades, apenas duas semanas após a aprovação da Lei Eusébio de Queirós, a qual proibia o tráfico de africanos e visava o fim das desavenças com a Inglaterra, o principal financiador das atividades produtivas do Brasil. A reforma da Guarda Nacional, medida levada a efeito no mesmo período, se inclui no aparato político administrativo necessário para assegurar a manutenção da ordem vigente, pois "buscava fortalecer a posição do governo perante os proprietários, cuja reação ao final do tráfico e às tentativas de regulamentação da posse da terra teria sido negativa" (SHWARCZ, 207, p. 102). A autora ainda cita a criação de um código comercial, também em 1850, objetivando a normatização de novos destinos para capitais empregados até então no tráfico, ou seja, as finanças, a produção agrícola, o comércio, as organizações políticas e sociais, enfim, tudo no Brasil se estruturava a partir da escravidão.

A presença de negros era fundamental na macro e na microestrutura socioeconômica, pois, além do trabalho na lavoura, sua participação ativa se fazia perceber em praticamente tudo que exigia mão de obra:

Entre as atividades mais comuns dos cativos estava a carga e descarga de mercadorias nos portos e nas ruas. Uma multidão deles trabalhava nas obras públicas, nos serviços urbanos, no comércio a retalho, no artesanato, nos espaços domésticos e em estabelecimentos comerciais (CARVALHO, 2018, p. 157-8).

Normalmente associados ao trabalho na agricultura, os escravizados exerciam ocupações urbanas na indústria, em matadouros, charutarias, chapelarias, havendo os de ganho ou de aluguel, que exerciam ofício de carpinteiro, barbeiro, sapateiro, alfaiate, ferreiro, marceneiro e outros, enquanto seu correspondente feminino eram as doceiras, as vendedoras ambulantes e as lavadeiras. No âmbito doméstico, nas cidades e nas áreas rurais, tinham atribuições de cozinheira, ama de leite, acompanhante, cabendo aos homens cuidados com animais, jardins, pomares, hortas etc. Compreende-se, pois, que negros como Luís Gama e Maria Firmina dos Reis, autora de Úrsula, publicado em 1859, ou mestiços como Machado de Assis e Paula Brito, entre outros, tenham se tornado exceções, pois aos africanos e seus descendentes era sonegado qualquer tipo de papel que não o de mão de obra forçada. Quando se considera a composição da população do 
Rio de Janeiro em meados do século XIX, pode-se ter uma dimensão mais precisa da situação dos negros, pois lá viviam "110 mil escravos para 250 mil habitantes (SCHWARCZ, 2017, p. 103). Os dados a seguir, são elucidativos:

Dos 65500 habitantes de Salvador em 1842, 27 500, ou seja, 42\%, eram cativos. Mesmo em decadência, Recife, por volta de 1828, possuía 7935 cativos em seus bairros centrais: $31 \%$ dos seus 25678 habitantes da sua parte mais urbanizada. Até Porto Alegre, quase à margem do tráfico atlântico de escravos mas enriquecida com o charque, em 1856, contava com o mesmo percentual de cativos de Recife de 1828: 30\%. (CARVALHO, 2018, p. 157).

Fatores como esses dão outras dimensões a negros e negras que conseguiram superar as enormes barreiras que tinham contra si e aproveitaram as frestas que encontraram para se dedicar à literatura, como fizeram os autores citados e outros tantos que ocuparam um espaço destinado naturalmente a brancos ricos. No caso de Luiz Gama, a relevância é ainda maior, pois independente do reconhecimento que sua produção tem alcançado, o fato é que nela se percebe consciência sobre as condições a que estava submetida grande parcela da população. É de se destacar, ainda, sua habilidade como poeta, perceptível pela maneira com maneja os recursos fonológicos e semânticos com o intuito de obter o maior efeito sonoro possível e dar organicidade à musicalidade poética, ou até mesmo quando quebra certas regras da versificação e, com isso, dá ao poema uma pulsão de caráter transgressor. Ademais, a linguagem simples e objetiva, recheada de termos correntes à época, pode ser entendida como busca de aproximação com o leitor e para facilitar a memorização, algo relevante naquele momento, quando boa parte da população era analfabeta, sendo a oralidade uma forma de acesso à literatura, em particular, à poesia.

Luiz Gama colocou seu talento poético e, principalmente, sua irreverência a serviço da luta contra o preconceito racial e no engajamento em favor da libertação dos escravos, demonstrando profunda consciência sobre o contexto socioeconômico em que vivia e negando-se a fazer concessões, contrariando um comportamento comum no meio literário de seu tempo. As atividades nos campos das letras eram uma forma de homens brancos alcançarem prestígio social, em especial os que não eram filhos da elite, razão pela qual muitos jovens se sentiam encorajados a publicar poesias pelas páginas de jornais, dedicando-as a moças de quem se diziam apaixonados, ou atacando desafetos, ou, ainda, defendendo causas políticas, no geral, encobertos por um pseudônimo. Esse contexto engrandece ainda mais a figura de Luiz Gama, porque mostra-se irrefreável, autêntico e destemido, pois, no lugar dos efeitos retóricos, das hipérboles e dos volteios sintáticos, optou por uma linguagem que se assemelha ao traço de um chargista, obtendo igual efeito no que se refere à fluidez, à corrosividade e à ironia, satirizando tudo e todos, inclusive a si próprio.

Em "Prótase", poema com o qual abre as Primeiras trovas de Getulino, recorrendo a recursos da tradição grega, revela contundência quanto aos seus propósitos, como se observa nas 
estrofes iniciais:

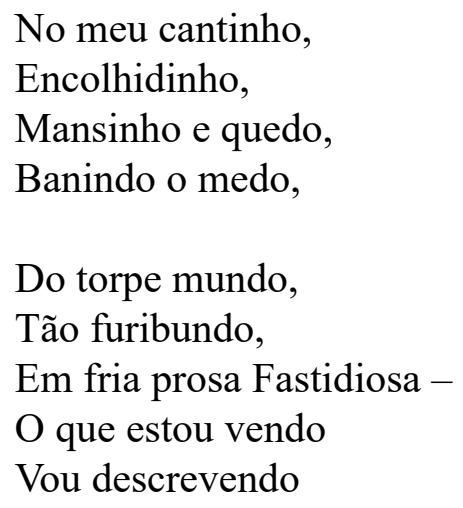

(GAMA, 2017)

O ponto, "meu cantinho", e o modo de observação, "encolhidinho", com o emprego do diminutivo, auferem valor de intensidade, o que dá ideia de oposição em relação ao tamanho do eu lírico e as dimensões do mundo que o rodeia. Considerando aquilo que se mencionou sobre o papel do negro na escravocracia brasileira, são elementos que indicam o abismo que separava o escravo de seu senhor, embora ocupassem os mesmos espaços físicos. Nesse particular, pesquisadores, relatos de estrangeiros que estiveram no Brasil e até formas de expressão artística, como a pintura e a literatura, mostram as contradições da escravidão no que se refere ao convívio entre negros e brancos. Apesar das demarcações rígidas quanto aos papéis, "A onipresença africana foi notada por praticamente todos os viajantes que estiveram no Rio de Janeiro, Salvador e Recife" (CARVALHO, 2018, p. 157). Estudos de sociólogos e historiadores revelam que a quantidade de negros e a sua presença em todas as atividades, em particular nas domésticas, compunham um estado de permanente violência, mesmo nas situações cotidianas, algo que Debret representa por uma imagem pungente no quadro Um jantar brasileiro. Na cena, um casal branco está à mesa diante de farta refeição, cercado por dois negros imóveis, porém visivelmente à disposição dos proprietários, e uma escrava que os abana, enquanto a mulher parece distrair-se com a distribuição de migalhas a duas crianças pretas como se animais fossem, e o homem se mantém absorto pelo prato a sua frente. O quadro ilustra a despersonalização pela destituição do livre arbítrio, uma brutalidade que se somava aos castigos físicos previstos pela legislação escravagista e a outras práticas violentas, entre elas a sexual, que vitimava as mulheres, costumeiramente, e os homens, com alguma recorrência, como apontam os historiadores.

No que se refere à representação de uma realidade com a qual Luiz Gama conviveu, naquilo que o eu lírico vê e descreve, observa-se que o enunciador destaca uma relação de desigualdade entre ele o meio que o cerca e, ao mesmo tempo, apresenta-se como espectador privilegiado, situado em uma posição que lhe permite enxergar tudo. Nesse sentido, a ironia de versos como os que seguem se potencializa:

São ritmos de tarelo, atropeladas,

Sem metro, sem cadência e sem bitola

Que formam no papel um ziguezague, 
Como os passos de rengo manquitola.

Grosseiras produções d'inculta mente,

Em horas de pachorra construídas;

Mas filhas de um bestunto que não rende

Torpe lisonja às almas fementidas

(GAMA, 2017)

Além do grande efeito irônico, as estrofes atestam a irreverência do autor ao tratar debochadamente daquilo que faz, remetendo ao prestígio desfrutado pelos homens de letras da época, alguns deles se fazendo admirar muito mais por se distanciar de sua realidade e pela erudição vazia do que pela capacidade de reflexão ou pelo talento literário. Paralelamente, o poeta ataca a elite branca, mostrando-se virulento diante da valorização das aparências, algo fundamental para uma sociedade cujas relações entre seus membros se dava pela hipocrisia das conveniências e pelo jogo de interesses. Essa intenção fica clara em estrofes como as que seguem:

São folhas de adurente cansanção,

Remédio para os parvos d'excelência;

Que aos arroubos cedendo da loucura,

Aspiram do poleiro alta eminência.

À frente parvalhões, heróis Quixotes,

Borrachudos Barões da traficância;

Quero ao templo levar do grão Sumano

Estas arcas pejadas de ignorância.

(GAMA, 2017).

Gama possibilita associações com um meio no qual o saber e a titulação garantiam respeitabilidade aos indivíduos, ainda que ambos tivessem um tanto de fraude, no primeiro caso revelada por indicações de pouco conhecimento e grande esforço para disfarçá-lo pelo emprego de uma erudição afetada e presunçosa e, no outro, porque as riquezas de titulados, por vezes, eram acumuladas de maneira escusa. Lilia Schwarcz afirma que a titulação representava o passaporte para pertencer ao círculo do imperador e "ser titular, ser nobre, era um privilégio de poucos" (2015, p. 161).

Luiz Gama diferencia-se de boa parte dos abolicionistas, porque poucos se dedicaram com tamanha disposição e de forma tão desinteressada ao combate da escravidão, sendo ainda caso raro de negro nascido livre transformado em cativo que, após reconquistar a liberdade, se dedicou à libertação de outros. Isso bastaria para que se transformasse em um indivíduo reconhecido na posteridade, tanto que o meio jurídico valorizou seu esforço humanitário, concedendo-lhe o diploma de advogado que foi negado em vida. Talvez o conhecimento jurídico que lhe possibilitou êxito na libertação de centenas de negros tenha a ver com a profunda percepção que tinha das relações de poder na sociedade brasileira de seu tempo e pela capacidade 
de interpretá-la, algo que seu lado poeta revela pela irreverência. Os versos a seguir, permitem essa interpretação:

Se o Governo do Império Brasileiro,

Faz coisas de espantar o mundo inteiro,

Transcendendo o Autor da geração,

O jumento transforma em sor Barão;

Se o estúpido matuto, apatetado,

Idolatra o papel de mascarado;

E fazendo-se o lorpa deputado,

N'Assembléia vai dar seu - apolhado!

(GAMA, 2017)

Na comparação dos números de títulos concedidos no Brasil e em Portugal, Lilia Schwarcz (2017) demonstra que agraciar endinheirados com essa honraria foi um dos pilares que sustentou a monarquia, embora aqui os critérios fossem diferentes, porque "A hereditariedade só era garantida para o sangue real, enquanto a titularidade se resumia ao seu legítimo proprietário" (p. 160). Nos versos citados, Luiz Gama trata corrosivamente de situações bastante comuns na nobreza brasileira, as quais são mencionadas pela historiadora quando afirma que os proprietários de terra constituíram parcela significativa dos titulados por D. Pedro II. Ela ressalva que, normalmente, recebiam o menor deles, o de barão e, ao mesmo tempo, salienta algumas características desses indivíduos quando se refere a estudiosos que falam "sobre os 'barões de tamanco' que trocavam os $r r$ pelos $f f$ que poucas letras conheciam"' (SCHWARCZ, 2017, p. 193).

Engendramento análogo ao da titulação também se observa na instituição do Poder Moderador ao monarca, mecanismo pelo qual Pedro II interferia diretamente nas decisões políticas de acordo com suas conveniências, transformando os cargos públicos em moeda de barganha e filtro de acesso ao interior do palácio real. O convívio com quem tomava as decisões garantia benesses, assim "Chegar ao poder significava obter prestígio e benefícios para si próprio e sua gente. Nas eleições não se esperava que o candidato cumprisse bandeiras programáticas, mas as promessas feitas a seus partidários" (FAUSTO, 2015, p. 98). Luiz Gama refere-se a esse tipo de relação, transformando irreverência, ironia e humor em instrumento de denúncia:

Se temos Deputados, Senadores,

Bons Ministros, e outros chuchadores;

Que se aferram às tetas da Nação

Com mais sanha que o Tigre, ou que o Leão;

Se já temos calçados - mac-lama

Novidade que esfalfa a voz da Fama,

Blasonando as gazetas - que há progresso,

Quando tudo caminha p'ro regresso:

(GAMA, 2017)

Ao denunciar os propósitos recrimináveis de ocupantes de cargos políticos e administrativos, referindo-se à inversão de valores que isso provocava por colocar interesses pessoais à 
frente da preocupação com o bem comum, Luiz Gama coloca-se em posição contrária aos escritores de seu tempo. É verdade que muitos deles, tanto poetas quanto prosadores, fazem críticas a costumes, denunciam a hipocrisia e o jogo de interesses nas relações socias e políticas, porém, expressam o ponto de vista de quem pertence ou se identifica com o segmento dominante e até mesmo quando reivindicam mudanças mais profundas, como aconteceu no engajamento das causas abolicionista e republicana, mantiveram essa posição. Pela voz do Orfeu da Carapinha, o poeta coloca-se do lado de fora, distanciando-se daquilo que descreve, como se percebe em "Lá vai verso":

Quero que o mundo me encarando veja, Um retumbante Orfeu de carapinha,

Que a Lira desprezando, por mesquinha,

Ao som decanta da Marimba augusta;

E, qual Arion entre os Delfins,

Os ávidos piratas embaindo -

As ferrenhas palhetas vai brandindo.

Com estilo que preza a Líbia adusta.

Com sabença profusa irei cantando

Altos feitos da gente luminosa,

Que a trapaça movendo portentosa

A mente assombra, e pasma à natureza!

Espertos eleitores de encomenda,

Deputados, Ministros, Senadores, Galfarros

Diplomatas - chuchadores,

De quem reza a cartilha de esperteza.

(GAMA, 2017)

Por outro lado, ao se incluir entre os responsáveis por aquilo que desaprova o poeta rebaixa aqueles que, pela riqueza, pelo cargo público, pelo título, por ser branco ou por tudo isso se situam na parte mais elevada da estratificação social, porque remete à condição do negro que sequer era reconhecido enquanto ser humano. Com isso, escancara o caráter injusto e perverso do escravismo:

Nem eu próprio à festança escaparei;

Com foros de Africano fidalgote,

Montado num Barão com ar de zote -

Ao rufo do tambor, e dos zabumbas,

Ao som de mil aplausos retumbantes,

Entre os netos da Ginga, os meus parentes,

Pulando de prazer e de contentes -

Nas danças entrarei d'altas caiumbas

(GAMA, 2017)

Concomitantemente, ao se dizer um Orfeu da Carapinha, o poeta neutraliza o que tem de pejorativo nas características do cabelo dos africanos, usando da irreverência para divinizar sua 
figura por meio da referência ao panteão da Grécia Antiga, o que pode ser tomado como ironia diante da nobreza brasileira, formada por indivíduos que compravam seus títulos e que eram destituídos de refinamentos, sem contar o artificialismo e a preocupação com as aparências. Lilia Schwarcz destaca que "Era importante não só utilizar o título certo como na hora certa: era proibido exagerar. [...] O segredo consistia, portanto, em fazer parecer natural o que era artificial o que na maioria das vezes foi entendido como natural (2017, p. 203).

Outra das mazelas da monarquia expostas por Luiz Gama foi a mestiçagem, não raro, decorrente da violência sexual praticada pelos senhores contra suas escravas, porém, como o negro estava associado ao servilismo, as pessoas procuravam se distanciar de sua ascendência africana. A Luiz Gama, isso não escapa:

Eis que brada um peralta retumbante;

- "Teu avô, que de cor era latente,

"Teve um neto mulato e mui pedante!"

Irrita-se o fidalgo qual demente,

Trescala a vil catinga nauseante,

E não pôde negar ser meu parente!

(GAMA, 2017)

O poeta tem na sátira a sua grande arma, sendo importante esclarecer que, aqui, a noção de sátira é simplificada, pois a complexidade que envolve essa forma de expressão leva a desvios necessários, ressalva justificada pelas controvérsias em torno do problema apontadas por quem se dedica a estudá-lo exaustivamente e admite a impossibilidade de se chegar a conclusões precisas $^{4}$. Durante o século XIX, a sátira desfrutava de pouco prestígio, pois estava associada a um público menos exigente, o que se observa pelo teatro, cujas representações com tal caráter não se destinavam aos ricos, ou a situações específicas, como se conclui diante de poemas criados para atacar adversários políticos ou desafetos, estampados nos jornais que circularam no período. Nesse sentido, Luiz Gama destaca-se tanto pela habilidade poética quanto pela desenvoltura com que se expressa no gênero ao qual se dedicou e, nesse campo, aparece entre os mais talentosos, sendo que, para alguns, é o melhor dentre os brasileiros, como afirma Heitor Martins (1996): "se não de toda literatura brasileira, é pelo menos o mais importante poeta satírico do Romantismo".

4 De acordo com estudiosos do assunto, a sátira é uma forma multifacetada e não se caracteriza como um gênero porque aparece em campos distintos, como o artístico e o jornalístico, portanto, não é exclusivamente de domínio estético, o que provoca desacordo entre os especialistas, os quais admitem estar diante de um fenômeno complexo que impossibilita definições conclusivas. Hernandez (1993) reconhece a inexistência de conceito capaz de expressar com precisão um termo que envolve sentidos presentes em quase todos os tipos de comunicação humana, enquanto Soethe (1998) destaca o consenso entre os teóricos quanto à imprecisão do que seja a sátira, e Leite (1992) afirma que seus limites são inapreensíveis, o que, para outros estudiosos, tema ver com sua capacidade de adaptação ou com o caráter polissêmico do termo. 


\section{Considerações finais}

Luiz Gama recorreu à sátira para fazer da jocosidade, da zombaria e da irreverência um instrumento de crítica social e de combate ao racismo, contestando a elite que forjava uma nobreza para se europeizar, a partir de títulos honoríficos obtidos pelo acúmulo de fortunas às custas do trabalho do escravo e que queria se distanciar do negro de todas as maneiras para dissimular a presença do sangue africano em suas veias. A irreverência do poeta assume caráter desestabilizador, pois, ao se apresentar como Orfeu da Carapinha, propõe-se a exercer um papel inverso ao do homônimo grego, porque, ao incluir-se entre aqueles de quem zomba, elimina o viés moralizador da sátira em suas origens na tradição europeia, sem deixar de expor as fissuras e as incongruências do escravagismo. Ao provocar o riso, Gama rompe os parâmetros pelos quais a ordem escravocrata se guiava, desestabilizando-a, porque contesta a autoridade senhorial, expondo suas contradições, como, por exemplo, o desrespeito às leis abolicionistas que criava. As fragilidades das estruturas que sustentavam a monarquia se faziam perceber por relações sociais e políticas pautadas pela hipocrisia, pelo jogo de interesses no qual o próprio imperador era figura chave, pela oposição entre a ideia de um grande império aos moldes europeus e uma população constituída por quase cinquenta por cento de negros, por conseguinte, em tal contexto não é ao poeta que faltava seriedade.

Nesse sentido, a poesia de Luiz Gama ocupa lugar ímpar na literatura brasileira, primeiro por sua condição de negro em contraste com o papel que cabia aos africanos e seus descendentes; segundo, que é o negro quem critica a escravidão, apontando a sua desumanidade, atacando as distorções que a mantinham sem a condescendência edulcorada comum a poetas abolicionistas. Outro aspecto pelo qual Gama se distingue é a visão realista com que encara a escravocracia, pois recorre à corrosividade para se contrapor à violência com que os brancos ricos se impunham; além disso, usou a irreverência com habilidade e seu nome deve constar entre os melhores poetas satíricos brasileiros, sendo insuperável no seu tempo. Por fim, aproveitou-se das frestas do sistema escravagista para resistir individualmente e proporcionar condições para que outros fizessem o mesmo.

Além do mais, são inegáveis as simetrias entre a trajetória literária de Luiz Gama e as suas ações para combater a escravidão e pelo reconhecimento dos negros enquanto cidadãos, como se conclui diante de seu engajamento na causa republicana, o que estabelece uma aproximação entre a sua atuação nos campos jurídico, político e estético. As especificidades da finalidade de cada um determinam correspondência nas distinções de seus respectivos discursos, uma vez que não se confundem, mas, no caso do poeta, quando confrontadas suas iniciativas em cada uma dessas áreas, percebe-se uma coerência que assegura unidade, portanto, que estabelece pontos de aproximações entre elas. Gama criou um eixo de convergência a partir da necessidade de empregar todos os recursos em favor daquilo que acreditava, impulsionado por vivências e em solidariedade a indivíduos que estavam condenados a um destino irreversível por causa da 
cor da sua pele. As experiências que viveu como escravo, certamente contribuíram para que se mostrasse indiferente ao entusiasmo inflamado que contaminou muitos abolicionistas, pois o fato de ser vendido pelo próprio pai deve ter sido determinante para que se conscientizasse de que havia uma distância oceânica entre brancos e pretos. O período em que ficou submetido à escravidão e aquilo que se sabe sobre sua biografia fazem crer que, não fosse por uma série de injunções favoráveis, jamais conseguiria recuperar sua liberdade, porque sua condição de negro bastava para condená-lo ao servilismo.

\section{Referências}

CARVALHO, M. J. M. Cidades escravistas. In: SCHWARCZ, L. M.; GOMES, F. S. (Orgs.). Dicionário da escravidão e liberdade. 50 textos críticos. São Paulo: Companhia das Letras, 2018. p. 156-168.

EMBAIXADA DE PORTUGAL. "Gabriela Amadeu (Brasil) vence $7^{\mathrm{a}}$ edição do Prêmio de Dramaturgia António José da Silva". Disponível em: < http://www.embaixadadeportugal.org. br/noticias/noticia.php?cod_noticia=373 >. Acesso em: $01 \mathrm{dez} .2018$.

FAUSTO, B. História concisa do Brasil. Colaboração de Sérgio Fausto. 3. ed. atualizada e ampliada. São Paulo: Edusp, 2015.

FERREIRA, L. F. "Luiz Gama por Luiz Gama: carta a Lúcio de Mendonça”. Disponível em: $<$ http://www.letras.ufmg.br/literafro/autores/28-critica-de-autores-masculinos/ 653-luiz-gama -por-luiz-gama-carta-a-lucio-de-mendonca-ligia-fonseca-ferreira >. Acesso em: 04 dez. 2018.

FOLHA DE SÃO PAULO. "Jeferson De roda filme sobre Luiz Gama, ex-escravo que libertou 500 pessoas". Disponível em: < https://www1.folha.uol.com.br/ilustrada/2018/11/jeferson-de-roda-filmesobre-luiz-gama-ex-escravo-que-libertou-500-pessoas.shtml $>$.

GAMA, L. Primeiras trovas burlescas de Getulino. Disponível em: < http://www.dominiopublico. gov.br/download/texto/bn000101.Pdf >. Acesso em: 07 jul. 2017.

. Carta a Lúcio de Mendonça. Disponível em: < http://www.letras.ufmg.br/literafr o/ autores/11-textos-dos-autores/651-luiz-gama-sao-paulo-25-de-julho-de-1880 >.

GELEDÉS: “Estreia do Espetáculo 'Luiz Gama - Uma Voz pela liberdade’ no Rio de Janeiro". Disponível em: < https://www.geledes.org.br/estreia-do-espetaculo-luiz-gama-uma-voz-pela -liberdade-no-rio-de-janeiro $>$.

HERNÁNDEZ, G. E. La satira chicana. México: Siglo Ventiuno, 1993.

INSTITUTO DOS ADVOGADOS DO BRASIL. Medalha Luiz Gama. Disponível em: $<$ https://www.iabnacional.org.br/institucional/medalha-luiz-gama >. Acesso em: 01 dez. 2018. 
MARTINS, H. Luiz Gama e a consciência negra na literatura brasileira. Salvador: Revista Afro-Ásia, n 17,1996 . Disponível em: < https://rigs.ufba.br/index.php/afroasia/issue/view /1453 /showToc >. Acesso em: 04 dez. 2018.

MINISTÉRIO DA CULTURA. Prêmio Luso-Brasileiro de Dramaturgia Antônio José da Silva - Nota de esclarecimento. Disponível em: < http://www.cultura.gov.br/noticias-destaques/-/ asset_publisher/OiKX3x1R9iTn/content/premio-luso-brasileiro-de-dramaturgia-antonio-josedasilva/10883 >. Acesso em: 01 dez. 2018.

PEREIRA, L. M. Machado de Assis: estudo crítico e biográfico. Brasília. Senado Federal, 2017.

SCHWARCZ, L. M.; GOMES, F. S. Introdução. In: (Orgs.). Dicionário da escravidão e liberdade. 50 textos críticos. São Paulo: Companhia das Letras, 2018.

SCHWARCZ, L. M. As barbas do imperador: D. Pedro II, um monarca nos trópicos. 2. ed. $17^{\mathrm{a}}$. Reimpressão. São Paulo: Companhia das Letras, 2017.

SENADO NOTÍCIAS. Leis sancionadas homenageiam abolicionista Luís Gama. Disponível em: < https://www12.senado.leg.br/noticias/materias/2018/01/17/leis-sancionadas-homenageia m-abolicionista-luis-gama >. Acesso em: 04 dez. 2018.

SOETHE, P. A. Sobre a sátira: contribuições da teoria literária alemã na década de 60. Fragmentos: Revista de língua e literatura estrangeira (Universidade Federal de Santa Catarina), v. 7, n. 2, 1998. 